„Śląskie Studia Polonistyczne” 2021, nr 2 (18)

ISSN 2353-0928

https://doi.org/10.31261/SSP.2021.18.09

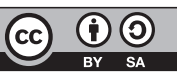

Opublikowano:

2.08.2021

\section{Tomasz Bąk}

\section{Uroki cyfryzacji}

Gdy wyszedłem z psem młodym czerwcowym wieczorem, by przez chwilę pokontemplować szczególny odcień nieba, który tylko czerwcowe niebo jest w stanie przybrać,

zobaczyłem chłopaka z telefonem w dłoni, wyzywanego zdalnie przez swoich kolegów, zagrzewającego kolegów do intensyfikacji wysiłków. 
Turniejowy czerwiec bez książki

selekcjonera piłkarskiej reprezentacji Polski, tak, ewidentnie dzieją się się rzeczy - no właśnie, jakie? Pamiętam, że miałem na to dość trafne określenie, gdy był rok 2012 (drobna, oczekiwana inwersja cyfr) i miał skończyć się świat. I co - faktycznie się skończył, na dziedzińcu łódzkiej kamienicy zgubiłem komputer dokładnie wiem, gdzie był, a mimo to zgubiłem w którym było kilka plików, z których prawdopodobnie gęsto bym się tłumaczył. Ale nie ma tego złego: gdy kończył się świat, grałem w NBA 2k na wykładzie z międzynarodowych stosunków gospodarczych, byłem nieco znudzony, Paul rzucał / Griffin łapał loby, prowadząca przedmiot poprosiła o definicję dialektyki proszę wyobrazić sobie powszechny popłoch, a potem przemnożyć to przez jakąś premier-dużą liczbę więc zdefiniowałem, i przeszło rok po świata końcu uzyskałem wpis w indeksie; pamiętam, że definiowałem bardziej z Marksa niż z Hegla, a poproszony o przykład, mówiłem o napięciu polityk płacowych w skali mikro-i makroekonomicznej, choć teraz, uwikłany w stosunek pracy, pewnie powiedziałbym coś zupełnie innego.

Dziewięć lat po końcu świata, gdy wiem już, że katastrofa jest stanem nie tylko zasłużonym, ale wręcz pożądanym, zasadniczo jestem smutny, gdy jestem bardziej wkurwiony niż smutny, i

jestem wkurwiony, gdy jestem bardziej smutny niż wkurwiony, wiem też, że pieniądz poniża wszystkich bogów człowieka i zamienia ich w towar, a także że nie ma przypadków, są tylko znaki, przeważnie niezbyt łaskawe. 
Opróżniona, waży około trzech kilogramów.

Tygodniami zbiera kurz w kącie biura, czekając cierpliwie na swoją kolej.

Jest niezastąpiona.

Niejednokrotnie dokonywała przemiany korporacyjnego szwindla w problem rozwiązany, spróbujcie pogadać o tym z Nixonem albo Stasi.

Przeraźliwe jęki kartek w szalenie szybko krążącym pyle, nierówna walka z kuwetą zbędnych dokumentów.

Bezradna bez prądu, gdy włożyć wtyczkę, skwapliwie i bez cienia protestu przerabia stosy papieru na konfetti, dopóki się nie przegrzeje.

Ma metaliczny połysk.

Obywa się bez instrukcji obsługi.

Jest wrażliwa na grubość i fakturę papieru, niekiedy wymaga interwencji w mechanizm.

Wyrazy uznania składane na piśmie ma najwyraźniej serdecznie w piździe. 


\section{Path of Wellness}

Pomyślmy drogę gminną, która może

zawierać śladowe ilości asfaltu, i jedźmy, jedźmy prosto po diagnozę:

od kilkunastu lat robię w literkach

(jakbyś nie zauważył, lokalny tygodniku),

a gdy tylko zaczynam o tym mówić, wstyd dosięga gardła, i to, co miało być zdaniem, rozpada mi się w palcach. To dobrze słyszę, choć nie wierzę - to dobrze, bardzo celnie oddaje pan to, co się wydarza. Trudno. Czy naprawdę muszę mówić o tym, co nieopłacone? Może by wystarczył równoważnik zdania? Uspokajam się na chwilę, ktoś na dole przypala, pada kilka krzepiących słów na temat trwającej próby oderwania się od materialnych podstaw egzystencji, diagnoza jednostki przeistacza się w diagnozę świata, przewieszam saszetkę przez ramię, czas wracać, by kochać cię dość, ale też by opowiadać szczątki ciężarówek na autostradach i to, jak brutalnie kwitną miasta woonerfione. 
Próbuję skupić się na oddechu, ale dwa bloki dalej warczy kosiarka (na pewno dwa bloki? Może trzy? Ciężko to sprawdzić z zamkniętymi oczami), i oczywiście mógłbym się podnieść, żeby zamknąć okno, ale żaden fragment instrukcji nie wspomina o zamknięciu okna, więc okno tymczasowo pozostaje otwarte.

Oddycham. Kosiarka! Ona to dopiero ma wydech! Gdy tak tnie i tnie całkiem dobrą przecież trawę, czy klatka piersiowa kosiarki unosi się i opada? Jasne, wszystko można strywializować, opowiedzieć niezły film w jednym (niezłym) zdaniu: koleśs myślat, że leci $w$ kosmos, a tak naprawdę przez cały czas był za regatem; dwa zdania dalej krytyka porządku pozostanie niewypowiedziana.

Byłoby przykro. Więc tak: opisywać kondycję świata za pomocą stanów psychicznych przytwierdzonego do świata bohatera lub podmiotu albo wyprowadzić najbardziej prawdopodobny stan psychiczny tkwiącego gdzieś w świecie bohatera lub podmiotu za pomocą rozmaitych wydarzeń i lapsusów wynikających bezpośrednio z kondycji świata zmęczyłem się, a chciałbym jeszcze o relacjach, żeby kondycja świata nie była tylko sumą przemierzających nasze wspaniałe miasta stanów psychicznych.

Ale przede wszystkim chciałem napisać o tym, że przy okazji usuwania niesatysfakcjonującego owłosienia maszynką elektryczną skróciłem się o znamię i historia, którą po powrocie z pracy będziesz czytać z mojej skóry, tym razem może zakończyć się inaczej. A także o tym, że w pewnym momencie użyteczne może okazać się zdrabnianie i spieszczanie czasowników, żeby twoja koleżanka, która przyszła zarabiać pieniążki, przez co siedzi cała w fakturkach i zamówionkach, mogła wykonywać wreszcie mniej poważne czynności. 


\section{Pamiątka po poprzednim właścicielu Anty-Edypa}

- Myślisz, że w innym ustroju społecznym byś nie zachorował?

- Myślę, że miałbym lepsze warunki do chorowania. 